\title{
EFFECT OF CONDENSED TANNINS AND SAPONIN SUPPLEMENTATION ON REPRODUCTIVE PERFORMANCE IN BARKI EWES
}

\author{
Rana M. A. Baheg', K. A. El-Bahrawy', K.M. El-Azrak ${ }^{2}$, M.A. Samak ${ }^{2}$ and S.M.A. \\ Sallam $^{2 *}$ \\ ${ }^{1}$ Department of Animal Physiology, Desert Research Center, Ministry of Agriculture and Land \\ Reclamation, Cairo, Egypt \\ ${ }^{2}$ Animal and Fish Production Department, Faculty of Agriculture, Alexandria University, Alexandria, \\ Egypt
}

(Received 9/3/2017, accepted 22/5/2017)

\section{SUMMARY}

$\mathrm{T}$ This study was carried out to investigate the effect of flushing diet supplementation with quebracho condensed tannins extract (QCTE), Yucca saponin extract (YSE), or combination of both on reproductive performance of Barki ewes. Forty ewes aged 3.7 years weighted $33.84 \mathrm{~kg}$ were divided into four equal groups, the first group (control) was received basal diet without treatment, while the second, third and fourth groups were received the basal diet plus $20 \mathrm{~g}$ of QCTE, $0.2 \mathrm{~g}$ of YSE or combination of both/ewe/d, respectively. This study was from four weeks premating to lambing. The treatments started before synchronization of estrus and mating of the ewes and continued for four weeks until mating The mean diameter of medium follicles were decreased $(\mathrm{P}=0.0245)$ with supplementation of YSE compared with combination of both QCTE+YSE. No significant differences were detected among QCTE , YSE, QCTE+YSE and control ewes on total number of follicles even large, medium or small follicles, diameter of large follicles, number and diameter of corpus luteum, number of services per conception and pregnancy rate. No significant effects were detected within treatments or with the control group on serum cortisol, estradiol or progesterone concentrations, while serum IGF-1 concentration was increased $(\mathrm{P}=0.005)$ in QCTE group in comparison with the YSE, QCTE+YSE and control ewes. Serum insulin concentration was increased $(\mathrm{P}=0.0001)$ with YSE group compared with other groups. The triiodothyronine concentration in serum was decreased $(\mathrm{P}=0.005)$ with YSE supplementation compared with QCTE+YSE and control ewes, while $\mathrm{QCTE}+$ YSE supplementation increased $(\mathrm{P}=0.007)$ serum thyroxin concentration in comparison with the QCTE, YSE and control groups. It can be concluded that flushing diet supplementation with quebracho condensed tannins extract (QCTE), Yucca saponin extract (YSE), or combination of both enhanced serum concentrations of IGF-1, insulin and T4 without positive impact on reproductive performance in Barki ewes.

Keywords: Quebracho, yucca, ovarian dynamics, fertility, blood metabolites

\section{INTRODUCTION}

Over the last two decades, several major reviews had addressed the topic about the relation between nutrition and reproduction in particular interest with sheep and goats (Martin et al., 2004). Reproduction in sheep had received much attention in Egypt owing to its high value as a source of animal protein (Sabra and Hassan, 2008), where fertility is one of the most important parameters of sheep productivity, the number of offspring obtained per lambing is a good indicator, and according to (Petrović, 2000) it is more important than gain of lambs. This means that, biological efficiency of sheep in regard to meat, milk and wool product conditioned by fertility (Notter, 2000). Feeding of sheep is also one of the most important factors that influence the fertility, flushing is understood as the rapid increase in ovulation rate of ewes receiving a nutrient supplementation before mating (Branca et al., 2000), as well as, affecting conception rate, lambing birth weight and lamb mortality with a significant effect on blood concentration of minerals, proteins and hormones (Sabra et al.1997).

In the past few decades, feed additives such as antibiotics were used in ruminant production for optimization of the rumen fermentation pattern, improve feed intake and feed efficiency (Patra, 2011). However, presently most of these supplements are not used routinely because of toxicity problems in the host animals and microbial adaptation. Consequently, the use of antibiotics as a feed additive has been banned in the European Union (European Union, 2003). Accordingly, using plants and plant extracts 
containing secondary compounds such as tannins and saponins with antimicrobial properties, which could be exploited in animal nutrition to manipulate rumen fermentation and improve feed efficiency (Sallam $e t$ al., 2009).Tannins are considered to have both beneficial and detrimental nutritional effects (Reed, 1995) including better utilization of dietary protein, faster body weight or wool growth, higher milk yield, increased fertility, and improving animal welfare and health through the prevention of bloat and reduced worm burdens (Mueller-Harvey, 2006).Several reviews in recent years were concerned with the implications or applications of saponins in animal production systems (Francis et al., 2002). Most of them, however, dealt with either specific sources or specific properties or biological effects of saponin on different animals. Saponins have variable effects on ruminal fermentation (Hristov et al., 1999). It has been shown in both in vitro(Hu et al., 2005) and in vivo (Yuan et al., 2007) that saponins might reduce the $\mathrm{pH}$ and ammonia-N concentration in the rumen, with a mixed effect on feed intake decreasing (Lovett et al., 2006), or increasing (Holtshausen et al., 2009) or either with no effect on feed intake in ruminants (Mao et al., 2010). Khalifa et al. (2014), concluded that saponin-rich plants have been found to favor high reproductive performance. Therefore, the aim of this study was to identify the effect of condensed tannins and saponin supplementation on reproductive performance in Barki ewes under fixed estrus synchronization protocol.

\section{MATERIALS AND METHODS}

\section{Location}

This study was carried out at Maryout Research Station, that belongs to the Desert Research Center (DRC), Ministry of Agriculture and Land Reclamation, located at $34 \mathrm{Km}$ west Alexandria (Lat: $31^{\circ} 0^{\circ}$ 17.748“ Long: $29^{\circ} 47^{\prime} 22.2504^{\prime \prime}$ ) and the Department of Animal Production, Faculty of Agriculture, Alexandria University, during the period form August 2014 to february 2015.

\section{Animal's management and experimental design}

Forty Barki ewes, average age 3.7 years old, with an average body weight of $33.76 \pm 0.74 \mathrm{~kg}$ were used in this study. Ewes were examined clinically to be free of any disease, physical abnormalities or reproductive disorders, and were divided randomly, based on age and body weight into four equal groups (no.=10). Animals were housed in freely well ventilated closed pens indoors. Fresh water was offered twice daily. Animals were fed on a pelleted concentrate feed mixture and ad lib. amount of Egyptian clover hay (Trifolium alexandrinum) to cover feed requirements of sheep according NRC (2007) allowances. Chemical composition of concentrate mixture and clover hay is shown in Table (1). First

Table (1). Chemical composition on dry matter basis of the experimental concentrate mixture and clover hay fed to ewes

\begin{tabular}{lcc}
\hline Chemical composition $(\mathrm{g} / \mathrm{kg})$ & Concentrate mixture & Clover hay \\
\hline Organic matter & 880 & 869 \\
Ash & 120 & 131 \\
Crude protein & 150 & 130 \\
Ether extract & 140 & 141 \\
Neutral detergent fiber & 532 & 571 \\
Acid detergent fiber & 317 & 364 \\
Hemicellulose & 215 & 207 \\
\hline Phytochemicals & & 6.80 \\
Total phenols (eq-g tannic acid kg-1 DM) & 6.10 & 1.40 \\
Total tannins (eq-g tannic acid kg-1 DM) & 0.70 & 0.06 \\
Condensed tannins (eq-g leucocyanidin kg & 0.03 & \\
\hline
\end{tabular}

group was the control group (Control) received basal diet without treatment, while the second group (QCTE) received basal diet plus 20g of QCTE /ewe/d, the third group (YSE) received the basal diet plus $0.2 \mathrm{~g}$ of YSE /ewe/d, and finally the forth group (QCTE+ YSE) received the basal diet plus both $20 \mathrm{~g}$ QCTE /ewe/d and 0.2g of YSE /ewe/d. The QCTE and YSE were mixed thoroughly with grinded pellets of concentration mixture. The origin of the commercial QCTE was from Argentine (Tanextra Ato Industria Argentina). The condensed tannins (CT) content of the investigated QCTE was 84.6\% analyzed 
according to (Yazaki and Hillis, 1980). The origin of the commercial YSE extract was from France (Free Trade Egypt for Import and Export). The total saponin content and steroidal saponin content of the investigated YSE was $4.5 \%$ and $0.03 \%$, receptively analyzed according to (Makkar et al., 2007). This study was from four weeks premating to lambing. The treatments started before synchronization of estrus and mating of the ewes and continued for four weeks until mating. Figure (1) presents the experimental procedure applied on ewes.

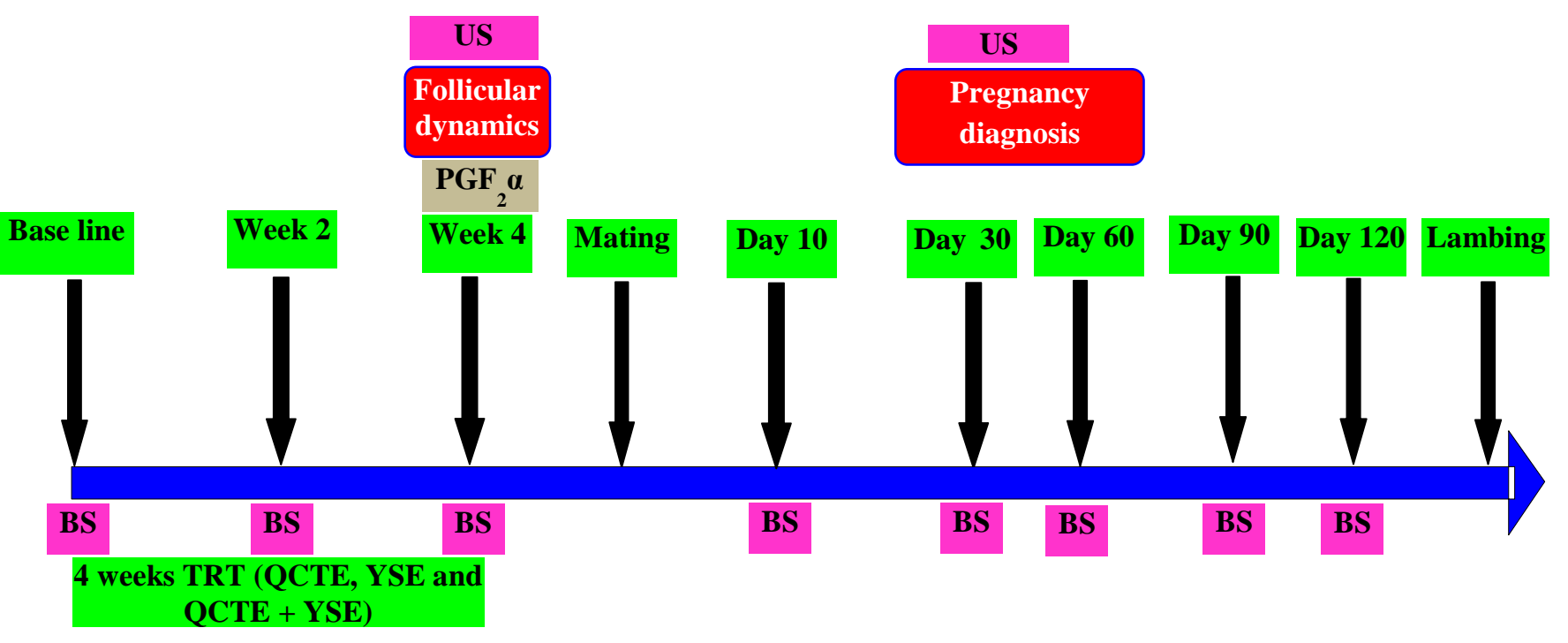

Blood sample (BS); Ultrasound examination (US).

Figure (1). Diagram of the experimental design

\section{Estrus synchronization}

All groups were synchronized for estrus using single intramuscular injection of $1 \mathrm{ml}$ prostaglandin $\mathrm{F}_{2 \alpha}$ $\left(\mathrm{PGF}_{2 \alpha}\right.$, Estrumate ${ }^{\circledR}, 250 \mu \mathrm{g}$ cloprostenol/ml, Schering-Plaugh Animal Health, Germany) according to (Abd El-Hamid, 2011). The ewes were presented to fertile rams that were fitted with dye markers to detect ewes exhibiting estrus. The PGF2 $\alpha$ injection was given at the end of the four weeks nutritional treatment.

\section{Ultrasound examination}

Ovarian activity and pregnancy diagnosis were examined by ultrasonography examination. Dynamic Imaging, concept MLV scanner ultrasound device (Eickemeyer Magic 5000 Digital), integrated with a dual frequency $(5.0$ and $7.5 \mathrm{MHz}$ ) linear array probe was used. The transducer was fitted to a plastic rod as an adaptor to enable manipulation of the probe after being inserted into the rectum approximately 10 $\mathrm{cm}$ deep. Ultrasound examination was conducted via the rectum on standing position. The ultrasound machine was connected to a thermal printer (Sony Video Graphic Printer UP-895MD) to document any information necessary during scanning sessions. Animals were banned from feed for $12 \mathrm{~h}$ before examinations. The examination method was performed according to (Abd El-Hamid, 2011). Animals were examined before synchronization of estrus by ultrasonography to determine the number and size of follicles and newly formed corpus luteum. Ultrasound scanning of uterine contents on d 30 after mating for early diagnosis of pregnancy and 60 to determine embryo survival rate.

\section{Ovarian activities and their implications}

The total number of follicles (TNF) in each ovary and diameter of each follicle were recorded. Follicles were classified into three categories according to their sizes (Naafia et al., 2011); small ( $<2$ $\mathrm{mm})$, medium $(2-4 \mathrm{~mm})$ and large $(>4 \mathrm{~mm})$. Ovulation was confirmed by disappearance of the largest follicle or presence of luteal structure (corpus luteum).

Reproductive performance 
Pregnancy was diagnosed by transrectal ultrasonography 30 days after natural mating and confirmed on day 60. Corpus luteum rate (CLR), estrus rate (ER), conception rate (CR), pregnancy rate (PR), fertility rate (FR), Prolificacy rate (PR), fecundity rate (FeR), abortion rate (AR), percentage of male $(\mathrm{PM})$ and percentage of female (PF) number of services per conception (NSPC) and gestation length (GL) were calculated according to (Hashem and El-Zarkouny, 2014) as the following equations:

$>$ Corpus luteum rate $=($ no. of ewes with corpus luteum $/$ no. of all ewes in herd $) * 100$

$>$ Estrus rate $=($ no. of ewes displaying estrus /no. of synchronized ewes $) * 100$

$>$ Conception rate $=($ no. of ewes pregnant/no. of ewes presented to rams $) * 100$

$>$ Pregnancy rate $=($ no. of ewes pregnant/no. of all ewes in herd $) * 100$

$>$ Fertility rate $=($ no. of ewes lambing/no. of ewes presented to rams $) * 100$

$>$ Prolificacy rate or litter size $=($ no. of lambs born/no. of ewes lambing) $* 100$

$>$ Fecundity rate or lambing rate $=($ no. of lambs born/no. of ewes presented to rams $) * 100$

$>$ Gestation length $=$ the period elapsed from conception till parturition

$>$ Number of services per conception $=$ (no. of services in pregnant ewes/ total number of conceived ewes)

$>$ Abortion rate $=($ no. of ewes aborting/no. of ewes pregnant $) * 100$

$>$ Percentage of male $=($ no. of male lambs/total number of lambs $) * 100$

$>$ Percentage of female $=($ no. of female lambs/total number of lambs $) * 100$

\section{Sampling and chemical analyses}

The concentrate mixture and Egyptian clover hay samples were dried at $55^{\circ} \mathrm{C}$ in a forced-air oven, grounded with a Wiley mill grinder to pass through a $1 \mathrm{~mm}$ stainless steel screen and then analyzed for dry matter (DM), organic matter (OM), ether extract (EE) and crude protein (CP) according to the analytical procedures of (AOAC , 2006). Neutral detergent fiber (NDF) (Van Soest et al., 1991) and acid detergent fiber (ADF) (Robertson and Van Soest, 1981) were determined in sequential analyses using an Ankom fibre analyzer (Fiber Analyzer A200; Ankom Technology, NY, USA). Total phenols (TP), total tannins (TT) and condensed tannins (CT) were analyzed according to (Makkar et al., 1993), respectively. Wet ash method for mineral analysis according to (Abou-Akkada and Naga, 1970). Phosphorus was determined by colorimetric method according to (May, 1959). In order to determine sodium (Na) and potassium (K) flame photometer (Flame Photometer PFP7 Jenway, UK) was used for absorption measurement. For determine magnesium $(\mathrm{Mg})$, calcium $(\mathrm{Ca})$, iron $(\mathrm{Fe})$, copper $(\mathrm{Cu})$, lead $(\mathrm{Pb})$, zinc $(\mathrm{Zn})$, cadmium $(\mathrm{Cd})$, manganese $(\mathrm{Mn})$ and chromium $(\mathrm{Cr})$ atomic absorption spectrometry (Atomic absorption spectrometry Thermo Elemental,UK) was used for absorption measurement.

Blood samples were collected from the jugular vein in vacationer tubes from all groups to get blood serum, before supplementation of QCTE, YSE and QCTE + YSE, during supplementation, at the end of supplementation before hormonal injections, after 10 days from injection, before each ultrasonographic scanning and monthly during gestation period. Serum total protein (TP), albumin (ALB), glucose (GLU), cholesterol (CHOL), triglyceride (TG), urea, creatinine (CRT), Alanine amino taransferase (ALT), aspartate amino taransferase (AST), calcium $(\mathrm{Ca})$, inorganic phosphorus $(\mathrm{P})$, potassium $(\mathrm{K})$ and sodium $(\mathrm{Na})$; were determined calorimetrically using visible light spectrophotometer (Spectrophotometer Alfa1502 V1.0 Labnics Equipment, USA). These parameters were determined using commercial colorimetric kits as manufactured by Spectrum Diagnostics Company, Germany. Globulin (GLO) concentration was calculated as the difference between total protein and albumin. Albumin globulin ratio (ALB/GLO) was calculated by dividing the albumin on the globulin. Calcium phosphorus ratio $(\mathrm{Ca} / \mathrm{P})$ was calculated by dividing the calcium on the phosphorus. Enzyme-Linked Immunosorbent Assay (ELISA) reader (Stat Fax 2100 Microplate Reader, Awareness Technologies Inc., USA) was used to measure serum progesterone (P4), estradiol (E2), Insulin-like growth factor 1 (IGF-1), insulin, triiodothyronine (T3), total thyroxine (T4) and cortisol by kits of DRG and Calbiotech, USA.

\section{Statistical Analysis}

Serum biochemical parameters, minerals, E2 and P4 concentrations were statistically analyzed as completely randomized design with repeated measures over time by using the MIXED procedure of SAS (SAS, 2002). Effects of treatment, week and the interaction of treatment $\times$ week with ewe being the random effect were defined by the F-test of ANOVA. The used model was as follow: $Y_{i j k}=\mu+Q_{i}+T_{j}+$ 
$(Q T)_{i j}+A_{k t}+E_{i j k}$; Where: $\mu$ is overall mean, $Q_{i}$ is a fixed effect of the treatment $(i=1-4), T j$ is a fixed effect of the time $(\mathrm{j}=1-4), \mathrm{QT}_{\mathrm{ij}}$ is an interaction between treatment $\times$ time, $\mathrm{A}_{\mathrm{kt}}$ is random effect of the animal (within treatment) and $\mathrm{E}_{\mathrm{ijk}}$ is the residual error. Data collected only once such as IGF-1, insulin, T3, T4 and cortisol were analyzed by t test. Comparisons among treatments were performed by Duncan's test. All results were expressed as means \pm standard errors. Significant differences were considered at $\mathrm{P}<$ 0.05 . The variables only measured once per animal total number of follicles (TNF), number of large follicles (NLF), number of medium follicles (NMF), number of small follicles (NSF), means diameter of large follicles (MDLF), means diameter of medium follicles (MDMF), means diameter of small follicles (MDSF), number of corpus luteum (NCL), means diameter of corpus luteum (MDCL), NSPC and GL were analyzed using the generalized linear model (GLM) procedure with treatment as main effect in the model. Categorical data or data expressed as percentages (CLR, ER, CR, PR, FR, PrR, FeR, AR, PM and PF) were analyzed by the chi-squared test.

\section{RESULTS AND DISCUSSION}

The effect of premating supplementation with quebracho condensed tannins extract (QCTE), Yucca saponin extract (YSE), or combination of both on ovarian follicular dynamics premating, NSPC after mating, GL after lambing in Barki ewes and reproductive performance parameters are presented in Table 2 and 3. No significant differences were detected between QCTE, YSE and QCTE + YSE and control ewes on TNF. Similar trend was recorded for NLF, NMF and NSF. No significant differences were detected between QCTE, YSE, QCTE + YSE and control ewes on MDLF. Also, No significant differences were detected between QCTE, YSE, QCTE + YSE and control ewes on CLR, ER, CR, PR, FR, PrR, FeR, AR and PM or PF. These findings were in accordance with those reported by (El-Gendy, 2014and Mirzaei and Prasad, 2011). Supplementation of YSE was the lowest on MDMF but did not differ significantly than the control group also MDMF decreased $(\mathrm{P}=0.0245)$ with supplementation of YSE (3.73 vs. $4.56 \mathrm{~mm})$ compared with QCTE + YSE. MDSF decreased $(\mathrm{P}=0.0334)$ with supplementation of YSE (2.41 vs. 2.81 and $2.79 \mathrm{~mm}$ ) compared with QCTE and control ewes. The results illustrated that there were no significant differences detected on NCL or MDCL, NSPC or GL within the treatments and the control group. These findings were in agreement with Vlčková et al.,(2017), where they found that feeding with yucca decreased $(\mathrm{P}=0.0029)$ follicle size from 2 to less than $5 \mathrm{~mm}$ in diameter, this could be due to an increase apoptosis, but not ovarian follicular cell proliferation on granulosa cells.

Table (2). Effect of premating supplementation with quebracho condensed tannins extract (QCTE), Yucca saponin extract (YSE) and combination of both on ovarian follicular dynamics, NSPC and GL in Barki ewes (means \pm SE)

\begin{tabular}{lccccc}
\hline Item & Control & QCTE & YSE & QCTE+YSE & P value \\
\hline TNF & $3.40 \pm 0.81$ & $4.20 \pm 0.80$ & $4.00 \pm 0.55$ & $3.80 \pm 0.97$ & 0.9059 \\
NLF & $1.00 \pm 0.45$ & $1.60 \pm 0.24$ & $0.80 \pm 0.37$ & $1.40 \pm 0.68$ & 0.6121 \\
NMF & $1.80 \pm 0.66$ & $2.20 \pm 0.37$ & $2.60 \pm 0.60$ & $1.60 \pm 0.40$ & 0.5572 \\
NSF & $0.60 \pm 0.40$ & $0.40 \pm 0.40$ & $0.60 \pm 0.40$ & $0.80 \pm 0.37$ & 0.9137 \\
MDLF (mm) & $5.49 \pm 0.26$ & $5.98 \pm 0.30$ & $6.21 \pm 0.35$ & $6.63 \pm 0.58$ & 0.3469 \\
MDMF (mm) & $4.09 \pm 0.09^{\mathrm{ab}}$ & $4.14 \pm 0.11^{\mathrm{ab}}$ & $3.73 \pm 0.22^{\mathrm{b}}$ & $4.56 \pm 0.20^{\mathrm{a}}$ & 0.0245 \\
MDSF (mm) & $2.79 \pm 0.07^{\mathrm{a}}$ & $2.81 \pm 0.04^{\mathrm{a}}$ & $2.41 \pm 0.14^{\mathrm{b}}$ & $2.54 \pm 0.06^{\mathrm{ab}}$ & 0.0334 \\
NCL & $1.00 \pm 0.45$ & $0.80 \pm 0.20$ & $1.20 \pm 0.37$ & $0.80 \pm 0.20$ & 0.7902 \\
MDCL (mm) & $6.58 \pm 0.88$ & $6.69 \pm 0.05$ & $6.85 \pm 0.59$ & $7.62 \pm 0.17$ & 0.4322 \\
NSPC & $1.29 \pm 0.18$ & $1.13 \pm 0.13$ & $1.00 \pm 0.00$ & $1.13 \pm 0.13$ & 0.4327 \\
GL (day) & $153.43 \pm 1.66$ & $151.50 \pm 1.84$ & $153.22 \pm 0.88$ & $153.29 \pm 0.87$ & 0.7216 \\
\hline Differen
\end{tabular}

Different letters $(a, b)$ in the same column indicate significant differences $(P<0.05) ;$ Total number of follicles $(T N F)$; Number of large follicles (NLF); Number of medium follicles (NMF); Number of small follicles (NSF); Means diameter of large follicles (MDLF); Means diameter of medium follicles (MDMF); Means diameter of small follicles (MDSF); Number of corpus luteum (NCL); Means diameter of corpus luteum (MDCL); Number of services per conception (NSPC) - (after mating); Gestation length (GL) - (after mating). 
Baheg et al.

Table (3). Effect of premating supplementation with quebracho condensed tannins extract (QCTE), Yucca saponin extract (YSE) and combination of both on reproductive performance parameters in Barki ewes (means $\pm \mathrm{SE}$ )

\begin{tabular}{lccccc}
\hline Item & Control & QCTE & YSE & QCTE + YSE & P value \\
\hline CLR (\%) & 60.00 & 80.00 & 80.00 & 80.00 & 0.8495 \\
ER (\%) & 80.00 & 100.00 & 90.00 & 100.00 & 0.2654 \\
CR (\%) & 87.50 & 80.00 & 100.00 & 80.00 & 0.5452 \\
PR (\%) & 70.00 & 80.00 & 90.00 & 80.00 & 0.7410 \\
FR (\%) & 87.50 & 80.00 & 100.00 & 70.00 & 0.3439 \\
PrR (\%) & 100.00 & 100.00 & 100.00 & 100.00 & NA \\
FeR (\%) & 87.50 & 80.00 & 100.00 & 70.00 & 0.3439 \\
AR (\%) & 0.00 & 0.00 & 0.00 & 12.50 & 0.3769 \\
PM (\%) & 42.86 & 37.50 & 55.56 & 57.14 & 0.8338 \\
PF (\%) & 57.14 & 62.50 & 44.44 & 42.86 & 0.8338 \\
\hline
\end{tabular}

CLR: corpus luteum rate - (premating); ER: estrus rate - (premating); CR: conception rate- (after mating); PR: pregnancy rate - (after mating); FR: fertility rate - (after lambing); PrR: prolificacy rate - (after lambing); FeR: fecundity rate - (after lambing); AR: abortion rate - (after lambing); PM: percentage of male - (after lambing); PF: percentage of female - (after lambing).

Effect of premating supplementation with QCTE, YSE, or combination of both on serum cortisol, IGF-1, insulin, T3 and T4 premating in Barki ewes are shown in Table (4). The results revealed that there were no significant effects within treatments or with the control group on serum cortisol concentrations. These results were in agreement with (Yami et al., 2000 and Jamra, 2012). While, serum IGF-1 concentrations increased $(\mathrm{P}=0.005)(94.80 \mathrm{ng} / \mathrm{mL})$ in QCTE group in comparison with the YSE, QCTE + YSE and control ewes these findings were in agreement with (Viñoles et al., 2012) at grazing lambs on improved pasture (mainly being Lotus corniculatus). These results may be explained by tannin role in enhancing the amino-acid bioavailability in the small intestine (Barry and McNabb, 1999). An increase in quality and quantity of AA supplied by AA bypassing degradation by the rumen can have an effect on hormonal influences of growth, especially the anabolic hormones, growth hormone (GH) and IGF-1 (Ragland-Gray et al., 1997), where hypothesized that the increased flow of AA to the abomasum could stimulate IGF-1 release because of the greater amount of AA absorbed into the blood. Davenport et al. (1995) also observed increased serum IGF-1 concentrations in lambs fed rumen-protected AA.

Table (4). Effect of premating supplementation with quebracho condensed tannins extract (QCTE), Yucca saponin extract (YSE) and combination of both on serum cortisol, insulin-like growth factor1 (IGF-1), insulin, triiodothyronine (T3) and thyroxin (T4) concentrations premating in Barki ewes (means \pm SE)

\begin{tabular}{lccccc}
\hline Item & Control & QCTE & YSE & QCTE+YSE & P value \\
\hline Cortisol $(\mathrm{ng} / \mathrm{ml})$ & $14.00 \pm 2.84$ & $20.33 \pm 2.54$ & $19.88 \pm 2.84$ & $17.69 \pm 2.54$ & 0.385 \\
IGF_1 $(\mathrm{ng} / \mathrm{mL})$ & $80.25 \pm 4.58^{\mathrm{b}}$ & $94.80 \pm 4.10^{\mathrm{a}}$ & $73.00 \pm 4.58^{\mathrm{b}}$ & $71.33 \pm 4.10^{\mathrm{b}}$ & 0.005 \\
Insulin $(\mu \mathrm{IU} / \mathrm{mL})$ & $2.77 \pm 0.76^{\mathrm{b}}$ & $4.10 \pm 0.68^{\mathrm{b}}$ & $8.70 \pm 0.76^{\mathrm{a}}$ & $4.47 \pm 0.68^{\mathrm{b}}$ & 0.0001 \\
T3 $(\mathrm{ng} / \mathrm{mL})$ & $0.63 \pm 0.04^{\mathrm{a}}$ & $0.53 \pm 0.04^{\mathrm{ab}}$ & $0.42 \pm 0.04^{\mathrm{b}}$ & $0.64 \pm 0.04^{\mathrm{a}}$ & 0.005 \\
T4 $(\mu \mathrm{g} / \mathrm{dl})$ & $3.95 \pm 0.29^{\mathrm{b}}$ & $3.76 \pm 0.26^{\mathrm{b}}$ & $4.35 \pm 0.29^{\mathrm{b}}$ & $5.20 \pm 0.26^{\mathrm{a}}$ & 0.007 \\
\hline
\end{tabular}

Different letters $(\mathrm{a}, \mathrm{b})$ in the same row indicate significant differences $(\mathrm{P}<0.05)$; SE: standard error; Insulin-like growth factor 1 (IGF-1); Triiodothyronine (T3); Thyroxin (T4).

Insulin concentrations increased $(\mathrm{P}=0.0001)$ with YSE supplementation $(8.70 \mu \mathrm{IU} / \mathrm{mL})$ compared with QCTE, QCTE + YSE and control ewes (4.10, 4.47 and $2.77 \mu \mathrm{IU} / \mathrm{mL}$, respectively), these results were also in agreement with (Devant et al., 2007). Fenugreek seed is known to its content of saponins as active substances (Hassan et al., 2016). Fenugreek treatment resulted in hypoglycemia in rabbits (Satayanarayana et al., 2003). Therefore, this herb has been used in the control of blood glucose levels in diabetic subjects since it contains some constituents that possess hypoglycemic properties (ShaneMcWhorter, 2001). Fenugreek seeds possess an insulin-like compounds, may be due to the presence of 
several compounds in Fenugreek seeds which enhances its effects in this regard or either stimulate pancreatic insulin secretion (Yadav et al., 2004). These reports may explain our results. The T3 concentrations decreased $(\mathrm{P}=0.005)$ with supplementation of YSE $(0.42 \mathrm{ng} / \mathrm{mL})$ compared with QCTE + YSE and control ewes, similar results were reported by (Elmnan et al., 2013). Fenugreek that contains saponin had stimulatory effects on thyroid gland lead to lower the active thyroid hormone T3 (Hassan et al., 2012). It can be observed that supplementing combination QCTE + YSE increased ( $\mathrm{P}=0.007)$ serum T4 concentrations $(5.20 \mu \mathrm{g} / \mathrm{dl})$ in comparison with the QCTE, YSE and control ewes $(3.76,4.35$ and 3.95 $\mu \mathrm{g} / \mathrm{dl}$, respectively). Hammond et al. (1984) reported that increase in T4 concentration in growing steers was related to the increased protein intake. Thus, the elevation of serum T4 concentration observed may be resulted from improved protein turnover after tannins and saponin action.

Table (5) shows the effect of premating supplementation with QCTE, YSE, or combination of both on serum E2 and P4 premating and during pregnancy in Barki ewes. Data showed that, there were no significant differences found on serum E2 or P4 concentrations. Also, time had no significant effect on E2 concentrations, while statistical analysis pointed out that the mean values of serum $\mathrm{P} 4$ concentrations were affected $(\mathrm{P}=0.0001)$ by the time. Also a significant interaction $(\mathrm{P}=0.0001)$ between treatment and elapsed time on serum E2 concentrations was detected, on the other hand no significance was detected between treatment and elapsed time on serum P4 concentrations. These findings were in accordance with those reported by (Ngokere et al., 2014) at oral administration doses 500 or $1000 \mathrm{mg} \mathrm{kg}^{-1}$ body weight/rabbit of methanol Mangifera Indica extract which contained tannins and Štochmal'ová et al. (2015) at addition Yucca schidigera to isolated and cultured rabbit ovarian fragments at dose of 10 or 100 $\mathrm{mg} / \mathrm{mL}$ medium for 48 hours.

Table (5). Effect of premating supplementation with quebracho condensed tannins extract (QCTE), Yucca saponin extract (YSE) and combination of both on serum estradiol (E2) and progesterone (P4) premating and during pregnancy in Barki ewes (means \pm SE)

\begin{tabular}{lccccccc}
\hline & & & & & & \multicolumn{2}{c}{ Pvalues } \\
\cline { 5 - 7 } Item & Control & QCTE & YSE & QCTE + YSE & Treat. & Time & Timex \\
Treat.
\end{tabular}

SE: standard error.

The effect of premating supplementation with supplementation of QCTE, YSE, or combination of both on serum biochemical metabolites premating and during pregnancy in Barki ewes are given in Table (6). The results showed that supplementation of QCTE, YSE and QCTE + YSE decreased $(\mathrm{P}=0.0001) \mathrm{TP}$ (5.67, 5.82 and 5.67g/dl, respectively) and GLO (3.10, 3.27 and $2.97 \mathrm{~g} / \mathrm{dl}$, respectively) concentrations in serum compared with control ewes $(6.13$ and $3.52 \mathrm{~g} / \mathrm{dl}$ for total protein and globulin, respectively). Also, statistical analysis pointed out that, the mean values of serum TP and GLO concentrations were affected $(\mathrm{P}=0.0001)$ by the time. Furthermore, no significant interaction between treatment and elapsed time on serum TP and GLO concentrations. These findings were in accordance with those reported by (Attia et al., 2016) at supplementation level $100 \mathrm{~g} / \mathrm{cow} / \mathrm{d}$ quebracho tannin and (Hassan et al., 2016) at supplementation of $2.5 \mathrm{~g} / \mathrm{goat} / \mathrm{kg}$ BW Fenugreek seeds. The decrease of TP and GLO concentrations values in supplemented ewes might be attributed to tannins, where tannins reported to decrease the digestibility of crude protein (Mahmoud, 2001), also, saponins decrease in rumen degradability of feed proteins (Makkar and Becker, 1996). Supplementing QCTE+YSE increased (P=0.004) serum ALB concentration $(2.70 \mathrm{~g} / \mathrm{dl})$ in comparison with the QCTE, YSE and control ewes $(2.57,2.55$ and $2.61 \mathrm{~g} / \mathrm{dl})$, respectively. Additionally, the mean values of serum ALB concentration were affected $(\mathrm{P}=0.0001)$ by the time. The results illustrated that supplementing QCTE + YSE increased $(\mathrm{P}=0.007)$ ALB/GLO ratio (0.95) compared with control ewes (0.79). The ALB/GLO ratio were also affected $(\mathrm{P}=0.0001)$ by the time. Moreover, no significant interaction between treatment and elapsed time on serum ALB concentration and ALB/GLO ratio. Our results were similar to those of (Singh et al, 2011) at 10\% level partially replaced deoiled mahua seed cake (Bassia latifolia) substitute deoiled soyabean meal. This increase of ALB concentration and ALB/GLO ratio in supplemented QCTE+YSE treatment might be attributed to 
the role of tannins and saponins to increase intestinal flow of amino acids, (Barry and McNabb, 1999 and Makkar and Becker, 1996). There is evidence that the ability of pregnant sheep to promote such net synthesis of albumin is sensitive to nutrition and that a relationship may exist between plasma concentration in late pregnancy and the extent of depletion of body protein reserves. It does appear, however, from the relationship between the change in plasma albumin concentration and body protein content that liver and muscle tissues may have similar priorities for available amino acids for synthesis of albumin and muscle protein, respectively, over a wide range of amino acid availability (Sykes and Thompson, 1978).

Table (6). Effecs of premating supplementation with quebracho condensed tannins extract (QCTE), Yucca saponin extract (YSE) and combination of both on serum biochemical metabolites premating and during pregnancy in Barki ewes (means $\pm \mathrm{SE}$ )

\begin{tabular}{|c|c|c|c|c|c|c|c|}
\hline \multirow[b]{2}{*}{ Item } & \multirow[b]{2}{*}{ Control } & \multirow[b]{2}{*}{ QCTE } & \multirow[b]{2}{*}{ YSE } & \multirow[b]{2}{*}{$\mathrm{QCTE}+\mathrm{YSE}$} & \multicolumn{3}{|c|}{$P$ values } \\
\hline & & & & & Treat. & Time & $\begin{array}{l}\text { Timex } \\
\text { Treat. }\end{array}$ \\
\hline $\mathrm{TP}(\mathrm{g} / \mathrm{dl})$ & $6.13 \pm 0.07^{\mathrm{a}}$ & $5.67 \pm 0.07^{b}$ & $5.82 \pm 0.07^{b}$ & $5.67 \pm 0.07^{b}$ & 0.0001 & 0.0001 & 0.737 \\
\hline $\operatorname{ALB}(\mathrm{g} / \mathrm{dl})$ & $2.61 \pm 0.03^{b}$ & $2.57 \pm 0.03^{\mathrm{b}}$ & $2.55 \pm 0.03^{b}$ & $2.70 \pm 0.03^{\mathrm{a}}$ & 0.004 & 0.0001 & 0.591 \\
\hline GLO (g/dl) & $3.52 \pm 0.08^{\mathrm{a}}$ & $3.10 \pm 0.07^{\mathrm{bc}}$ & $3.27 \pm 0.07^{\mathrm{b}}$ & $2.97 \pm 0.07^{\mathrm{c}}$ & 0.0001 & 0.0001 & 0.658 \\
\hline ALB/GLO ratio & $0.79 \pm 0.03^{\mathrm{b}}$ & $0.86 \pm 0.03^{\mathrm{ab}}$ & $0.86 \pm 0.03^{\mathrm{ab}}$ & $0.95 \pm 0.03^{\mathrm{a}}$ & 0.007 & 0.0001 & 0.906 \\
\hline GLU (mg/dl) & $43.53 \pm 0.94$ & $46.92 \pm 0.90$ & $44.70 \pm 0.86$ & $45.81 \pm 0.90$ & 0.057 & 0.0001 & 0.142 \\
\hline CHOL (mg/dl) & $80.88 \pm 1.4^{\mathrm{ab}}$ & $79.15 \pm 1.33^{\mathrm{b}}$ & $84.81 \pm 1.28^{\mathrm{a}}$ & $82.8 \pm 1.3^{\mathrm{ab}}$ & 0.018 & 0.0001 & 0.654 \\
\hline $\mathrm{TG}(\mathrm{mg} / \mathrm{dl})$ & $20.48 \pm 0.91$ & $19.43 \pm 0.87$ & $19.06 \pm 0.84$ & $21.19 \pm 0.87$ & 0.281 & 0.0001 & 0.0001 \\
\hline Urea (mg/dl) & $42.54 \pm 0.85$ & $42.12 \pm 0.81$ & $41.54 \pm 0.78$ & $40.83 \pm 0.81$ & 0.490 & 0.0001 & 0.0001 \\
\hline CRT (mg/dl) & $0.90 \pm 0.03$ & $0.92 \pm 0.03$ & $0.96 \pm 0.03$ & $0.94 \pm 0.03$ & 0.515 & 0.0001 & 0.0001 \\
\hline $\mathrm{ALT}(\mathrm{U} / \mathrm{L})$ & $16.92 \pm 0.55^{b}$ & $16.90 \pm 0.52^{\mathrm{b}}$ & $19.72 \pm 0.50^{\mathrm{a}}$ & $20.74 \pm 0.52^{\mathrm{a}}$ & $\begin{array}{l}0.000 \\
1\end{array}$ & 0.0001 & 0.0001 \\
\hline AST (U/L) & $34.23 \pm 1.62$ & $31.99 \pm 1.55$ & $33.18 \pm 1.49$ & $35.45 \pm 1.40$ & 0.437 & 0.0001 & 0.042 \\
\hline
\end{tabular}

Despite YSE supplementation was the highest on serum CHOL concentration but did not differ significantly in comparison with the control group, while YSE increased $(\mathrm{P}=0.018)$ serum cholesterol concentrations $(84.81 \mathrm{mg} / \mathrm{dl})$ compared with QCTE $(79.15 \mathrm{mg} / \mathrm{dl})$. Additionally, statistical analysis showed that the mean values of serum $\mathrm{CHOL}$ concentration were affected $(\mathrm{P}=0.0001)$ by the time. Furthermore, no significant interaction between treatment and elapsed time on serum CHOL concentration. Ashour et al. (2014) was in agreement with our results at supplementation level $200 \mathrm{mg}$ Yucca schidigera extract/kg diet/rabbit. A great number of studies had shown a hypo-cholesterolemic effect of saponins in mammals. However; so far, there is no information on the effects of saponins on cholesterol metabolism in ruminants. There are two school of thoughts emerging for the hypocholesterolemic effect of saponins: (i) a direct binding between saponins and dietary cholesterol in the gut, which prevents its absorption from the small intestine and (ii) a binding between saponins and bile acids in the gut, which decreases the enterohepatic circulation of bile acids and increases cholesterol excretion with feces (Sidhu and Oakenfull, 1986). These hypotheses were formulated through studies on monogastric animals. Considering that ruminants' diets do not contain cholesterol, the first hypotheses above mentioned is not valid. Moreover, saponins are structurally modified by ruminal microorganisms (Wang et al., 1998) and it is likely that the aglycone remaining after saponin degradation is not as effective as the entire saponin in binding bile acids in the gut. This would explain why hypocolesterolemic effects of saponins in lambs were not observed by (Brogna et al., 2011) and in our results.

As for serum GLU, TG, urea, CRT and AST concentrations, no significant differences were found within treatments and control group, however, statistical analysis pointed out that the mean values of GLU, TG, urea, CRT and AST concentrations were affected $(\mathrm{P}=0.0001)$ by the time .No significant interaction between treatment and elapsed time on serum GLU concentration. Significant interaction $(\mathrm{P}=0.0001)$ between treatment and elapsed time on serum $\mathrm{TG}$, urea and CRT concentrations but interaction was $(\mathrm{P}=0.042)$ between elapsed time and treatment on serum AST concentration. Similar 
findings had been reported by Zhou et al. (2014) where they did not found significant effect in plasma GLU, TG, urea and AST concentrations, also Pathak et al. (2016) did not found significant effect in serum CRT concentration that for tannins. On the other hand Kumar et al. (2017) found that supplementation $2.6 \%$ of total DMI tea seed saponin did not significant affect serum GLU, TG, urea, CRT and AST concentrations. Moreover, YSE and QCTE+YSE groups, increased $(\mathrm{P}=0.0001)$ serum ALT concentration (19.72 and $20.74 \mathrm{U} / \mathrm{L}$, respectively) in comparison with the QCTE and control ewes (16.90 and $16.92 \mathrm{U} / \mathrm{L}$, respectively). Mean values of ALT concentrations were affected $(\mathrm{P}=0.0001)$ by the time and interaction $(\mathrm{P}=0.0001)$ between treatment and elapsed time. These findings were in accordance with those reported by (Shams Al-dain and Jarjeis, 2015). Larson (1985) attributed the significantly increased to the effect of fenugreek seeds that contain saponin to stimulate the liver function.

Effect of premating supplementation with QCTE, YSE, or combination of both on serum minerals premating and during pregnancy in Barki ewes are shown in Table (7). The results showed that supplementation in spite of QCTE supplementation was the highest on serum Ca concentration did not differ significantly than the control, moreover QCTE increased $(\mathrm{P}=0.019)$ Ca concentration (3.09 $\mathrm{mmol} / \mathrm{l}$ ) in serum compared with YSE and QCTE+YSE (2.31 and $2.28 \mathrm{mmol} / \mathrm{l}$, respectively). Statistical analysis pointed out that the mean values of serum Ca concentration were affected $(\mathrm{P}=0.009)$ by the time. However, there were no significant interaction between treatment and elapsed time on serum Ca concentration, to some extent; the closest results to our results were reported by (Eissa et al., 2015). Supplementation with QCTE, YSE and QCTE+YSE were decreased $(\mathrm{P}=0.0001)$ serum $\mathrm{P}$ concentration $(2.40,2.31$ and $2.04 \mathrm{mmol} / \mathrm{l}$, respectively) in comparison with the control group $(2.82 \mathrm{mmol} / \mathrm{l})$.

Table (7). Effecs of premating supplementation with quebracho condensed tannins extract (QCTE), Yucca saponin extract (YSE) and combination of both on serum minerals premating and during pregnancy in Barki ewes (means \pm SE)

\begin{tabular}{|c|c|c|c|c|c|c|c|}
\hline \multirow[b]{2}{*}{ Item } & \multirow[b]{2}{*}{ Control } & \multirow[b]{2}{*}{ QCTE } & \multirow[b]{2}{*}{ YSE } & \multirow[b]{2}{*}{$\mathrm{QCTE}+\mathrm{YSE}$} & \multicolumn{3}{|c|}{$P$ values } \\
\hline & & & & & Treat. & Time & $\begin{array}{l}\text { Timex } \\
\text { Treat. }\end{array}$ \\
\hline $\mathrm{Ca}(\mathrm{mmol} / \mathrm{l})$ & $2.59 \pm 0.20^{\mathrm{ab}}$ & $3.09 \pm 0.20^{\mathrm{a}}$ & $2.31 \pm 0.20^{\mathrm{b}}$ & $2.28 \pm 0.20^{\mathrm{b}}$ & 0.019 & 0.009 & 0.050 \\
\hline $\mathrm{P}(\mathrm{mmol} / \mathrm{l})$ & $2.82 \pm 0.10^{\mathrm{a}}$ & $2.40 \pm 0.10^{\mathrm{b}}$ & $2.31 \pm 0.10^{\mathrm{bc}}$ & $2.04 \pm 0.10^{\mathrm{c}}$ & 0.0001 & 0.213 & 0.026 \\
\hline $\mathrm{Ca} / \mathrm{P}$ ratio & $0.94 \pm 0.09^{b}$ & $1.34 \pm 0.09^{\mathrm{a}}$ & $1.06 \pm 0.09^{b}$ & $1.17 \pm 0.09^{\mathrm{ab}}$ & 0.021 & 0.012 & 0.052 \\
\hline $\mathrm{K}(\mathrm{mmol} / \mathrm{l})$ & $6.30 \pm 0.17$ & $6.39 \pm 0.17$ & $6.25 \pm 0.17$ & $6.19 \pm 0.17$ & 0.848 & 0.0001 & 0.681 \\
\hline $\mathrm{Na}(\mathrm{mmol} / \mathrm{l})$ & $135.14 \pm 1.4^{\mathrm{a}}$ & $129.56 \pm 1.42^{b}$ & $127.95 \pm 1.4^{\mathrm{b}}$ & $126.64 \pm 1.4^{b}$ & 0.0001 & 0.0001 & 0.860 \\
\hline
\end{tabular}

Different letter $(a, b, c)$ in the same row indicate significant differences $(P<0.05)$; SE: standard error; Calcium $(C a)$; phosphorus (P); Calcium/phosphorus ratio (Ca/P ratio); Potassium (K); Sodium (Na).

Conversely, the mean values of $\mathrm{P}$ serum concentration pointed out that no significant effect by the time. On the other, there were significant interaction $(\mathrm{P}=0.026)$ between elapsed time and treatment on serum $\mathrm{P}$ concentrations. Moreover, the supplementation of QCTE, YSE and QCTE + YSE were decreased Na serum concentration $(\mathrm{P}=0.0001)$ with values $(129.56,127.95$ and $126.64 \mathrm{mmol} / \mathrm{l}$, respectively) compared with the control group $(135.14 \mathrm{mmol} / \mathrm{l})$ also, statistical analysis elucidated that serum $\mathrm{Na}$ concentration was affected $(\mathrm{P}=0.0001)$ by elapsed time. On the other hand, no significant interaction between treatment and elapsed time on serum Na concentration. Our results were similar to those of (Min et al., 2015a) where they found significant decreased on serum $\mathrm{P}$ concentration, also, (Min et al., 2012) where they found significant decreased on serum $\mathrm{Na}$ concentration that for tannins. In the same time, (Mousa and Orabi, 2014) found significantly decreased value of serum $\mathrm{P}$ and Na concentrations at feeding roughage fresh berseem (Trifolium alxandrinum) that contain saponin. The results noticed that supplementation of QCTE (1.34) was increased $(\mathrm{P}=0.021)$ serum $\mathrm{Ca} / \mathrm{P}$ ratio compared to supplementation of YSE and the control group (1.06and 0.94, respectively). The mean values of $\mathrm{Ca} / \mathrm{P}$ ratio were affected $(\mathrm{P}=0.012)$ by the time, while no significant interaction between treatment and elapsed time on $\mathrm{Ca} / \mathrm{P}$ ratio was observed. These results may be due to ewes supplemented QCTE was the highest in serum Ca concentration comparable with other treatments and decreased significantly in serum $\mathrm{P}$ concentration in comparison with the control group. Data showed that the treatments had no significant differences on serum $\mathrm{K}$ concentrations. But, statistically, the mean values of serum $\mathrm{K}$ concentration were affected $(\mathrm{P}=0.0001)$ by the time. However, there were no significant interaction between elapsed time and treatment on serum $\mathrm{K}$ concentration. Our results were similar to those of (Olafadehan, 2011 and Gümüş and İmik 2016). It is 
well known that CT can precipitate proteins, but we do not know whether protein precipitation or metal chelation by the polyphenolic groups CT can affect mineral absorption (Min et al., 2015b). Supplementation QCTE led to decreased serum P and Na concentrations significantly. This effect may be primarily due to a low apparent absorption pre-abomasum in the CT-containing diet compared with nonCT-containing control diet animal (Waghorn and Barry, 1987). Lower absorption is probably a consequence of two main factors: 1) complexation between CT and minerals preventing absorption; 2) effects of CT upon the intestinal mucosa resulting in impaired or delayed absorption (Waghorn et al., 1999). However, ewes supplemented with QCTE was the highest in serum Ca concentration comparable with other treatments, that maybe due to a nutrient specific effect of CT on minerals in the gastrointestinal track, another mechanisms suggested that may be involved in the reactions between dietary CT and minerals, with the minerals that are more selectively absorbed offering more opportunity for retention in the body to be improved through the action of CT (Min et al., 2015b). In the meantime, ewes supplemented with YSE was the lowest in serum Ca concentration comparable with other treatments and led to decreased serum $\mathrm{P}$ and $\mathrm{Na}$ concentrations significantly, it is proposed that one mechanism of action whereby saponins formation insoluble saponin-mineral complexes, impairing mineral absorption in the gastrointestinal tract. Such complexes could reduce the availability of minerals where irritation of the gastrointestinal tract, changes in intestinal transit time, inhibition of cellular metabolic enzymes, inhibition of digestive enzymes, and decreased availability of nutrients due to saponin-nutrient complexation (West et al., 1978).

\section{CONCLUSION}

Flushing diet supplementation with quebracho condensed tannins extract (QCTE), Yucca saponin extract (YSE), or combination of both enhanced serum concentrations of IGF-1, insulin and T4 without positive impact on reproductive performance in Barki ewes.

\section{REFERENCES}

Abd El-Hamid, I.S. (2011). Effect of protected fatty acids supplementation on reproductive performance of Barki ewes. M.SC thesis, Faculty of Agriculture, Alexandria University, Egypt.

Abou-Akkada, A.R. and M. A. Naga (1970). Methods of Food Analysis. Dar El-Maaref $1^{\text {st }}$ edition, Faculty of Agriculture. Alexandria University, Egypt, pp. 125.

AOAC. (2006). Official methods of analysis of AOAC International, $20^{\text {th }}$ edition, AOAC International, Arlington, VA, USA.

Ashour, E.A., M., Alagawany, F. M., Reda and M. E., Abd El-Hack (2014). Effect of supplementation of Yucca schidigera extract to growing rabbit diets on growth performance, carcass characteristics, serum biochemistry and liver oxidative status. Asian Journal of Animal and Veterinary Advances, 9 (11): 732-742.

Attia, M. F. A., A. N. M. Nour El-Din, S. Z. El-Zarkouny, H. M. El-Zaiat, M. M. Zeitoun and S. M. A. Sallam (2016). Impact of quebracho tannins supplementation on productive and reproductive efficiency of dairy cows. Open Journal of Animal Sciences, 6:269-288.

Barry TN and W.C. McNabb (1999). The implications of condensed tannins on the nutritive value of temperate forages fed to ruminants. The British Journal of Nutrition, 81:263-272.

Branca, A., G. Molle, M. Sitzia , M. Decandia and S. Landau (2000). Short-term dietary effects on reproductive wastage after induced ovulation and artificial insemination in primiparous lactating Sarda ewes. Animal Reproduction Science, 58:59-71.

Brogna, D. M. R., S. Nasri, H. Ben Salem, M. Mele, A. Serra, M. Bella, A. Priolo, H. P. S. Makkar, and V. Vasta (2011). Effect of dietary saponins from Quillaja saponaria L. on fatty acid composition and cholesterol content in muscle Longissimus dorsi of lambs. Animal, 5(7):1124-1130.

Davenport, G. M., J. A. Boling and K. K. Schillo (1995). Growth and endocrine responses of lambs fed rumen-protected ornithine and arginine. Small Ruminant Research, 17:229-236. 
Devant, M., A. Anglada and A. Bach (2007). Effects of plant extract supplementation on rumen fermentation and metabolism in young Holstein bulls consuming high levels of concentrate. Animal Feed Science and Technology, 137:46-57

Eissa, M. M., W. M. A. Sadek, A. R. Khattab, A. EL-Wakeel and A. M. Saber (2015). Impact of feeding some fodder trees and treated crop residues on barki lambs performance under semi-arid area of Egypt. Egyptian Journal of Animal Production, 52:69-77.

EL-Gendy, M. N. A. (2014). Study on the relationship between nutrition and reproduction in sheep. M.SC thesis, Faculty of Agriculture, Alexandria University, Egypt.

Elmnan, B.A.A., N.M. Jame, S.A. Rahmatalla, E.O. Amasiab and A.G. Mahala (2013). Effect of Fenugreek (Trigonella foenumgraecum) seeds supplementation on feed intake, some metabolic hormones profile, milk yield and composition of Nubian goats. Research Journal of Animal science, $7(1): 1-5$.

European Union. (2003). Regulation (EC) No. 1831/2003 of the European parliament of the council of 22 September 2003 on additives for use in animal nutrition. Official Journal of the European Union, 268:29-43.

Francis, G., Z. Keem , H. P. S. Makkar and K. Becker (2002). The biological action of saponins in animal systems: a review. British Journal of Nutrition, 88:587-605.

Gümüş, R. and H. İmik (2016). The effect of Yucca schidigera powder added to lamb feed on fattening performance, some blood parameters, the immune system, and the antioxidative metabolism of the hepatic tissue. Turkish Journal of Veterinary and Animal Sciences, 40:263-270.

Hammond, A. C., G. B. Huntington and J. Bitman (1984). Effect of nitrogen intake on and rhythmicity of circulating thyroid hormones in steers. Domestic Animal Endocrinology, 1:29-42.

Hashem, N. M. and S. Z. El-Zarkouny (2014). Effect of short-term supplementation with rumenprotected fat during the late luteal phase on reproduction and metabolism of ewes. Journal of Animal Physiology and Animal Nutrition, 98: 65-71.

Hassan,S.A.A., S.A.I. Shaddad, K. Salih, A. Muddither, S. I. Kheder and M.A. Barsham (2012). Effects of oral administration of Trigonella foeum L. (Fenugreek seeds) on galactogoue, body weight and hormonal levels in Sudanese desert sheep. Journal of Pharmaceutical and Biomedical Science, 22(24):1-4.

Hassan, S. A. A., S. A. I. Shaddad, A. K. Muddathir and A.E. H. Mohammed (2016). Effect of fenugreek seeds (Trigonella Foeum-graecuml.) on heamatological and biochemical performance of pregnant and non pregnant ewes. World Journal of Pharmaceutical Research, 5(5):260-265.

Holtshausen, L., A.V. Chaves, K. A. Beauchemin, S. M. McGinn, T. A. McAllister, N. E.Odongo, P. R. Cheeke, and C. Benchaar (2009). Feeding saponin-containing Yucca schidigera and Quillaja saponaria to decrease enteric methane production in dairy cows. Journal of Dairy Science, 92:2809-2821.

Hristov, N.A., T. A. McAllister, F. H. Van-Herk, K. J. Cheng, C. J. Newbold and P. R. Cheeke (1999). Effect of Yucca schidigera on ruminal fermentation and nutrient digestion in heifers. Journal of Animal Science, 77:2554-2563.

Hu, W. L., J. X. Liu, J. A. Ye, Y. M. Wu and Y. Q. Guo (2005). Effect of tea saponin on rumen fermentation in vitro. Animal Feed Science and Technology, 120:333-339.

Jamra, M.S. (2012). Effect of herbal feed supplement shatavari (Asparagus racemosus) on growth and sexual maturity of Sahiwal heifers. M.SC thesis, Deemed University, India

Khalifa, E. I., H. A. M. Hassanien , A. H. Mohamed and A. Abdel-El-Magied (2014). Effect of using yucca schidigera powder as feed additive on productive and reproductive efficiency of Zaraibi dairy goats. Egyptian Journal of Sheep and Goat Sciences, 9 (2): 9-21.

Larson, P.L. (1985). Biosynthesis and cellular secretion of milk. In:lactation, $1^{\text {st }}$ Edition, Ames: Iowa State University Press, USA, Chapter 4, pp. 129-163. 


\section{Baheg et al.}

Lovett, D. K., L. Stack, S. Lovell, J. Callan, B. Flynn, M. Hawkins and F. P. O. Mara (2006). Effect of feeding Yucca schidigera extract on performance of lactating dairy cows and ruminal ermentation parameters in steers. Livestock Science, 102:23-32.

Kumar, M., A. Kannan, R. Bhar, A. Gulati, A. Gaurav and V. K. Sharma (2017). Nutrient intake, digestibility and performance of Gaddi kids supplemented with tea seed or tea seed saponin extract. Asian-Australasian Journal of Animal Sciences, 30(4):486-494.

Mahmoud, H. A. (2001). Physiological and nutritional studies on sheep feeding certain halophytic plants in Sinai. M. Sc. Thesis, Faculty of Agriculture, Cairo University, Egypt.

Makkar, H. P. S., M. Blummel, N. K. Borowy and K. Becker (1993). Gravimetric determination of tannins and their correlation with chemical and protein precipitation methods. Journal of the Science of Food and Agriculture, 61:161-165.

Makkar, H. P. S. and K. Becker (1996). Effect of pH, temperature, and time on inactivation of tannins and possible implications in detannification studies. Journal of Agricultural and Food Chemistry, 44:1291-1295.

Makkar, H., P. Siddhuraju and K. Becker (2007). Plant secondary metabolites. Institute for Animal Production in the Tropics and Subtropics, Humana Press, $1^{\text {st }}$ edition, Hohenheim University, Stuttgart, Germany, pp. 93-100.

Mao, H. L., J. K.Wang, Y. Y. Zhou and J. X. Liu (2010). Effects of addition of tea saponin and soybean oil on methane production, fermentation and microbial population in the rumen of Growing lambs. Livestock Science, 129:56-62.

Martin, G.B., G.T.B. Milton, R.H. Davidson , G.E. B. Hunzicker, D.R. Lindsay and D. Blache (2004). Natural methods for increasing reproductive efficiency in small ruminants. Animal Reproduction Science, 82-83: 231-246.

May, R. (1959). Determination of quinquevalent, trivalent, and organic phosphorus in the atmosphere and in aqueous solutions. Analytical Chemistry, 31:308-310.

Min, B. R., S. Solaiman, N. Gurung, J. Behrends, J. S. Eun, E. Taha and J. Rose (2012). Effects of pine bark supplementation on performance, rumen fermentation, and carcass characteristics of Kiko crossbred male goats. Journal of Animal Science, 90:3556-3567.

Min, B. R., E. A. Wilson, S. Solaiman and J. Miller (2015a). Effects of condensed tannin rich pine bark diet on experimentally infected with Haemonchus Contortus in meat goats. International Journal of Veterinary Health Science and Research, 3(3):49-57.

Min, B. R. , S. Solaiman, T. Terrill, A. Ramsay and I. Mueller-Harvey (2015b). The effects of tanninscontaining ground pine bark diet upon nutrient digestion, nitrogen balance, and mineral retention in meat goats. Journal of Animal Science and Biotechnology, 6 (25):2-8.

Mirzaei, F. and S. Prasad (2011). Influence of dietary phytoadditive as polyherbal combination on performance of does and respective litters in cross bred dairy goats. Asian-Australasian Journal of Animal Sciences, 24(10):1386 - 1392.

Mousa, S.A. and S. Orabi (2014). Growth performance, rumen fermentation parameters and selected serum macro and micro mineral in Egyptian steers fed on berseem hay. Global Veterinaria, 13 (2): 233-236.

Mueller-Harvey, I. (2006). Unravelling the conundrum of tannins in animal nutrition and health. Journal of the Science of Food and Agriculture, 86: 2010-2037.

Naafia, S., W. A. A. Razzaque, M. M. Rao and K. Hussain (2011). Nitric oxide profiles in serum and follicular fluid of cyclic and acyclic sheep. Journal of Research and Development, 11:119-128.

Ngokere, A.A., C.P. Ezeofor, J.O. Okoye, S.N. Ibekailo, T. Ude, C.J. Awalu and M.S. Amadi (2014). Antiprogesteronic and estrogenic effect of Mangifera indica in female rabbits. Journal of Pharmacology and Toxicology, 9(2):82-89.

Notter, D. R. (2000). Effects of ewe age and season of lambing on prolificacy in US Targhee, Suffolk, and Polypay sheep. Small Ruminant Research, 38:1-7.

NRC. (2007). Nutrient Requirements of Small Ruminants, Sheep, Goats, Cervids, and New World Camelids. The National Academic Press, Washington DC, USA. 
Olafadehan, O. A. (2011). Changes in hematological and biochemical diagnostic parameters of Red Sokoto goats fed tannin-rich Pterocarpus erinaceus forage diets. Veterinarski Arhiv, 81 (4):471-483.

Pathak, A. K., N. Dutta, A. K. Pattanaik and K. Sharma (2016). Influence of condensed tannins supplementation through ficus infectoria and psidium guajava leaf meal mixture on nutrient intake and clinical chemistry in lambs. Journal of Animal Research, 6 (2): 15-25.

Patra, A. K. (2011). Effects of essential oils on rumen fermentation, microbial ecology and ruminant production. Asian Journal of Animal and Veterinary Advances, 6:416-428.

Petrović, P.M. (2000). Genetics and Improvement of Sheep (monograph).Scientific Book, Belgrade, pp. 365.

Ragland-Gray, K. K., H. E. Amos, M. A. McCann, C. C. Williams, J.L. Sartin, C.R. Barb and F.M. Kautz (1997). Nitrogen metabolism and hormonal responses of steers fed wheat silage and infused with amino acids or casein. Journal of Animal Science, 75: 3038-3045.

Reed, J.D. (1995). Nutritional toxicology of tannins and related polyphenols in forage legumes. Journal of Animal Science, 73:1516-1528.

Robertson, J.B. and P.J. Van Soest (1981). The detergent system of analysis. In: The analysis of dietary fiber in food, James, W.P.T. and O. Theander (Editors), Marcel Dekker, New York,USA, Chapter 9, pp. 123-158.

Sabra, H. A., W. M. Ahmed and O. H. Ezzo (1997). Effect of flushing with sunflower seeds meal on some blood plasma metabolites during the different reproductive phases in Barki ewes. Beni-suef Veterinary Medical Research, 7:260-275.

Sabra, H.A. and S.G. Hassan (2008). Effect of new regime of nutritional flushing on reproductive performance of Egyption Barki ewes. Global Veterinaria, 2 (1): 28-31.

Sallam, S. M. A., I. C. S. Bueno, P. Brigide, P. B. Godoy, D. M. S. S. Vitti and A. L. Abdalla (2009). Efficacy of eucalyptus oil on in vitro ruminal fermentation and methane production. Options Mediterraneennes, 85:267-272.

SAS (2002). SAS User's Guide. Statistical Analyses Systems Institute, Inc, Cary, NC, USA, pp. 549-640.

Satayanarayana, S., G.S. Saima, A. Ramesh, K. Sushruta and N. Srinivas (2003). Evaluation of herbal preparations for hypoglycemic activity in normal and diabetic rabbits. Pharmaceutical Biology, 41, 466-472.

Shams Al-dain, Q. Z. and E. A. Jarjeis (2015). Evaluation of using some medical herbs seeds as feed supplementation and their effects on the activity of some enzymes and hormones on male Awassi lambs. Kufa Journal for Veterinary Medical Sciences, 6 (1):97-108.

Shane-McWhorter, L. (2001). Biological complementary therapies: a focus on botanical products in diabetes. Diabetes Spectrum, 14:199-208.

Sidhu, G.S. and D.G. Oakenfull (1986). A mechanism for the hypocholesterolaemic activity of saponins. British Journal of Nutrition, 55:643-649.

Singh, P., A.K. Verma, A.B. Jacob, S.C. Gupta and U.R. Mehra (2011). Haematological and biochemical changes in Fasciola gigantica infected buffaloes fed on diet containing deoiled mahua (Bassia latifolia) seed cake, Journal of Applied Animal Research, 39(3):185-188.

Stochmal'ová, A., M. Földešiová, A. Baláži, A. Kádasi, R. Grossmann, R. Alexa, P. Chrenek and A. V. Sirotkin (2015). Yucca schidigera extract can promote rabbit fecundity and ovarian progesterone release. Theriogenology, 84: 634-638.

Sykes, A. R. and R. Thompson (1978). The relationship between serum albumin concentration and body protein loss in pregnant sheep. Journal of Agricultural Science, Cambridge, 91:173-179.

Van Soest, P. J., J. B. Robertson and B. A. Lewis (1991). Methods for dietary fibre, neutral detergent fibre and nonstarch polysaccharides in relation to animal nutrition. Journal of Dairy Science, 74: 3583-3597. 


\section{Baheg et al.}

Viñoles, C., I. De Barbieri, J. Gil, J. Olivera, S. Fierro, F. Bialade and F. Montossi (2012). Long-term effect of nutrition on the metabolic status and reproductive potential of Merino rams under grazing conditions. Animal Production Science, 52:881-889.

Vlčková, R., D. Sopková, Z. Andrejčáková, I. Valocký, A. Kádasi, A. Harrath, V. Petrilla and A. V. Sirotkin (2017). Dietary supplementation of yucca (Yucca schidigera) affects ovine ovarian functions. Theriogenology,88: 158-165.

Waghorn, G. C. and T. N. Barry (1987). Pasture as a nutrient source. In: Livestock feeding on Pasture, Nicol, A.M. (Editor), New Zealand society of animal production occasional publication, Private Bag, Hamilton, New Zealand,10:21-37.

Waghorn, G. C., J. D. Reed and L. R. Ndlovu (1999). Condensed tannins and herbivore nutrition. In: Buchanan-Smith, J. G., L. D. Bailey and P. McCaughey (Editors), Proceedings of the XVIII International Grasslands Congress, Association Management Centre, Calgary, Alberta, Canada, pp. 153-166.

Wang, Y., T.A. McAllister, C.J. Newbold, L.M. Rode, P.R. Cheeke and K. J. Cheng (1998). Effects of Quillaja saponaria extract on fermentation and degradation of steroidal saponins in the rumen simulation technique (RUSITEC). Animal Feed Science and Technology, 74:143-153.

West, L. G., J. L. Greger, A. White and B.J. Nonnamaker (1978). In vitro studies on saponin-mineral complexation. Journal of Food Science, 43:1342-1343.

Yadav, U.C., K. Moorthy and N. Z. Baquer (2004). Effects of sodium-orthovanadate and Trigonella foenum graecum seeds on hepatic and renal lipogenic enzymes and lipid profile during alloxan diabetes. Journal of Biosciences, 29:81-91.

Yami, A. , A. J. Litherlandb, J. J. Davisb, T. Sahlub, R. Puchalaband and A.L. Goetschb (2000). Effects of dietary level of Leucaena leucocephala on performance of Angora and Spanish doelings. Small Ruminant Research, 38:17-27.

Yazaki, Y. and W.E. Hillis (1980). Molecular size distribution of radiate pine loark extracts and its effect on properties. Holzforschung, 34:125-130.

Yuan, Z. P., C. M. Zhang, L. Zhou, C. X. Zou, Y. Q. Guo, W. T. Li, J. X. Liu and Y. M. Wu (2007). Inhibition of methanogenesis by tea saponin and tea saponin plus disodium fumarate in sheep. Journal of Animal and Feed Sciences, 7:560-565.

Zhou, Z., B. Zhou, L. Ren and Q. Meng (2014). Effect of ensiled mulberry leaves and sun-dried mulberry fruit pomace on finishing steer growth performance, blood biochemical parameters, and carcass characteristics. Plos One, 9(1): e85406.

\section{تأثير إضافة التانينات المكثفة و الصابونين على الأداء التناسلي في النعاج البرقي}

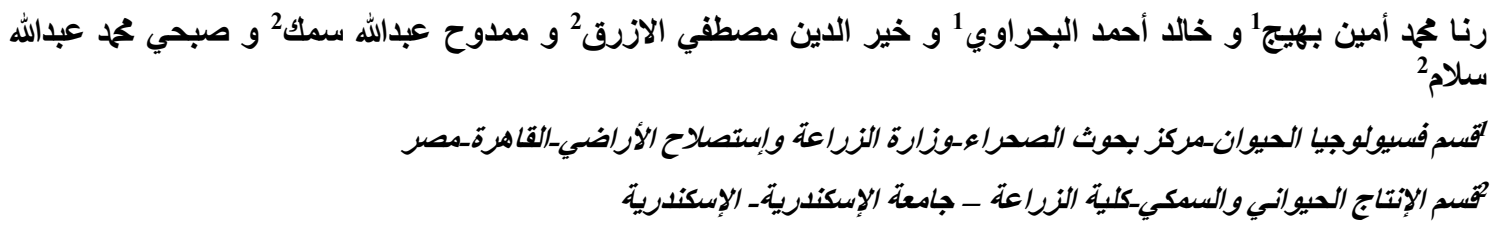

أجريت هذه الدراسة لاستقصاء تأثثر علائق الدفع الجنسي المضاف لها مستخلص تانينات الكابراتشو المكثفة, مستخلص اليوكا

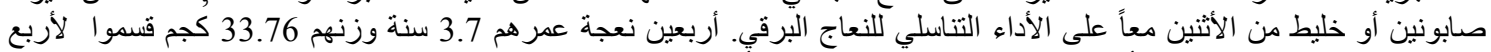

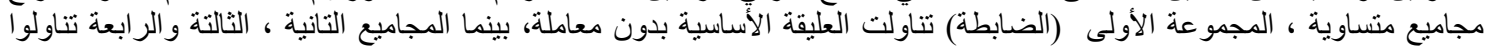

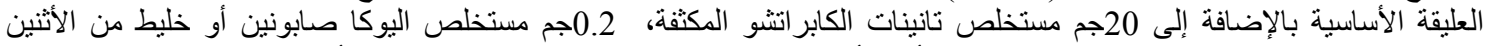

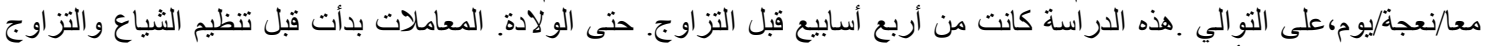

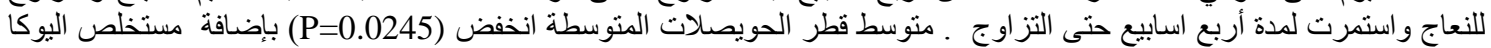

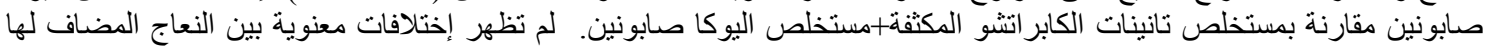

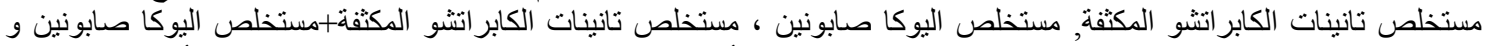

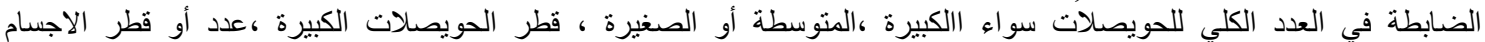

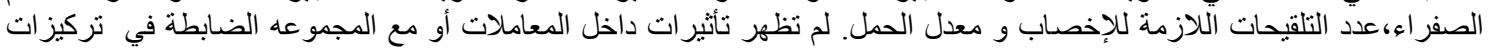

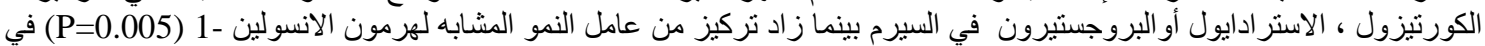




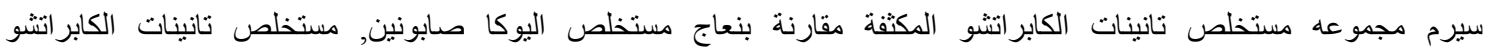

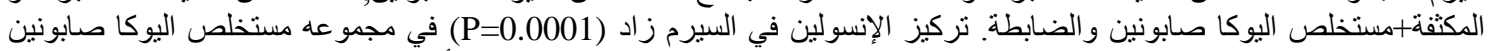

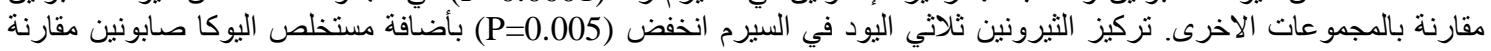

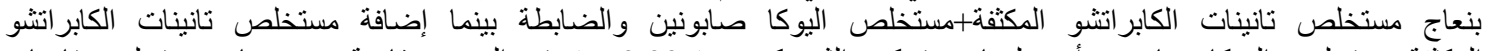

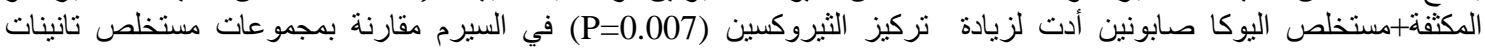

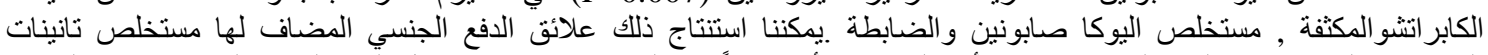

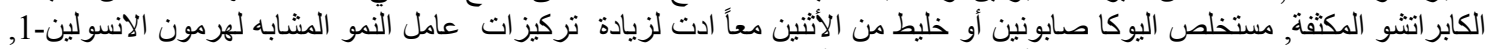

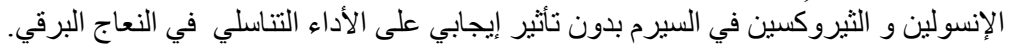

